\title{
The Economic Benefits of Education
}

\section{More Education Improves National and State Economy}

- The longer individuals spend in education, the more likely they are to be in employment and earn more. Nearly $75 \%$ of countries with the greatest increase in the percentage of young people with college degrees also showed higher incomes and lower unemployment. ${ }^{1}$

- Each graduate provides a "public gift" worth $\$ 127,000$. By cutting high school dropouts in halt, America saves $\$ 45$ billion annually. ${ }^{2}$

- The return investment on education is 2.5 times the cost. ${ }^{3}$

- Education levels are linked to salaries, tax revenue, and productivity. One study found that cutting state K-12 spending by $\$ 1$ per $\$ 1,000$ could reduce income by 3.2 percent. $^{4}$

- Increasing spending on education balances economic inequalities and reduces poverty. ${ }^{5}$

\section{Education Increases Civic Participation}

- $\quad$ At every age, those with more education are more likely to vote. ${ }^{6}$

- $\quad$ Those with more education are more likely to volunteer. ${ }^{7}$

\section{More Learning Results in More Earnings}

- Compared to a high school dropout, a high school graduate is more than three times as likely to earn an income of at least $\$ 75,000$ a year, and three times as likely to earn at least six figures. ${ }^{8}$

- A high school graduate will earn an average of 1.4 times the annual full-time salary of a high school dropout; a person with some college will earn 1.75 times, and a four-year degree 3 times as much as the dropout. ${ }^{9}$

\section{Education Moves Citizens from Welfare Recipients to Productive Citizens}

- High school graduates need $40 \%$ less welfare. ${ }^{10}$

- The unemployment rate of high school dropouts (over 25 in 2006) was 6.8\%, which is more than 3 times the rate for that of a college graduates. ${ }^{11}$

- Dropouts cost society up to $\$ 8,000$ more in average welfare and aid than high school graduates (for African-American males, for white females, the difference is $\$ 1,615) .{ }^{12}$

\section{Education Lowers Crime Costs}

- Incarceration is on average $\$ 22,650$ per year. ${ }^{13}$

- States spend on average 3 times more per prisoner than per public school student. ${ }^{14}$

- The death rate for high school dropouts us 2.5 times higher than for graduates. ${ }^{15}$

\section{Education Lowers Health Care Costs}

- People with more education are more likely to be in good health than people of similar age but less education. ${ }^{16}$

- Among Americans over 65, just 26 percent of dropouts, but 40 percent of high school graduates and 55 percent of college graduates report excellent or very good health. ${ }^{17}$

\footnotetext{
${ }^{1}$ Organization for Economic Co-Operation and Development, Education at Glance (2007).

http://www.oecd.org/dataoecd/60/47/39311361.pdf

${ }^{2}$ Center for Benefit-Cost Studies of Education at Teachers College, Columbia University, The Costs and Benefits of an Excellent Education for All of America's Children (2007), http://www.cbcse.org/media/download_gallery/Leeds_Report_Final_Jan2007.pdf.

${ }^{3} I d$.

${ }^{4}$ National Education Association, The K-12 Education in the U.S. Economy. Its Impact on Economic Development, earning and Housing Values. (2004). http://www.nea.org/edstats/images/economy.pdf

${ }^{5}$ National Education Association, The Effects of State Public K-12 Education Expenditures on Income Distribution (2004). http://www.nea.org/edstats/images/expenditures.pdf

${ }^{6}$ Baum and Pavea (2004) Education Pays. Citing U.S. Census Bureau, 2002b, Table 5.

${ }^{7}$ Baum and Pavea (2004) Education Pays. Citing Bureau of Labor Statistics, 2003.

${ }^{8}$ U.S. Census Bureau, Historical Income Tables. Census 2005 figures at http://pubdb3.census.gov/macro/032005/perinc/new03_010.htm

${ }^{9}$ U.S. Census Bureau, Historical Income Tables. "Educational Attainment--People 25 Years Old and Over by Mean Income and Sex: 1991 to 2006.” Table P-18 at http://www.census.gov/hhes/www/income/histinc/p18.html.

${ }^{10}$ The Costs and Benefits of an Excellent Education for All of America's Children at http://www.cbcse.org/media/download_gallery/Leeds_Report_Final_Jan2007.pdf
} 


\section{The Economic Benefits of Education}

\footnotetext{
${ }^{11}$ National Center for Education Statistics, Digest of Education Statistics 2007. Table 369, "Unemployment Rate of persons 16 years old and over, by age, sex, race/ethnicity, and educational attainment: 2004, 2005, and 2006” at http://nces.ed.gov/programs/digest/d07/tables/dt07_369.asp?referrer=list

${ }^{12}$ Baum and Pavea (2004) Education Pays. citing Vernez, Krop and Rydell (1999) Closing the Education Gap: Benefits and Costs. Santa Monica, California: RAND

${ }^{13}$ Children's Defense Fund, America's Cradle to Prison Pipeline (2007).

${ }^{14}$ Id.at 20.

${ }^{15}$ Center for Labor Market Studies, Northwestern University, Youth labor market and education indicators for the state of Illinois. Chicago, IL: Alternative Schools Network (2003).

${ }^{16}$ Baum and Pavea (2004) Education Pays. Citing NCES, 2004, Indicator 12 (based on National Health Interview Survey, National Center for Health Statistics, 2001).

${ }^{17}$ Baum and Pavea (2004) Education Pays. Citing NCES, 2004, Indicator 12 (based on National Health Interview Survey, National Center for Health Statistics, 2001).
} 